\title{
Climate Change Impact to the Water Resources of Eastern Caucasus (Kura Basin) Rivers and Ways of Its Mitigation
}

\author{
Rafig Verdiyev \\ 36, Huseynbala Aliyev str. Apt 52, Baku, AZ1111, Azerbaijan
}

\begin{abstract}
This article is about assessment of climate change impact to water resources of Eastern Caucasus rivers for different period in the past and expected future trends by use of different sceneries. According to the results of assessment increase of air temperature in last 30 years for about 0.5-1.0 degree Celsius lead to reduction of flow by $5 \%$. In regions where in addition to rising of temperature also precipitations are reduced this figure makes $10 \%$. According to climate sceneries increase of air temperature in the future for 4.0-4.5 degree Celsius may lead to reduction of water resources for 30\%. Different measures of adaptation have been identified in the article to combat water scarcity linked to impact of climate change.
\end{abstract}

Key words: Water discharges, river, temperature, precipitation, flow, water use.

\section{Introduction}

The fresh surface water resources of Azerbaijan mainly consist run-off of Kura and its tributaries Araz and Ganikh (Alazan) basins rivers, and those which fall directly into the Caspian Sea, including transboundary rivers Samur (flows through the Russian Azerbaijan border) and Astarachay (flows through the Azerbaijan and Iran border).

Kura with its vast river system is the key water provider or, as hydrologists say, is the main water artery of the Caucasus. The river flows through the territories of Turkey, Georgia and Azerbaijan Republics. The total length of the river is $1,364 \mathrm{~km}$ (of which $185 \mathrm{~km}$ relates to the territory of Turkey, 390 to Georgia and $790 \mathrm{~km}$ to Azerbaijan). Total watershed area is $188,000 \mathrm{~km}^{2}$ (of which $58,000 \mathrm{~km}^{2}$ relates to Azerbaijan, $34,700 \mathrm{~km}^{2}$ to Georgia, $29,800 \mathrm{~km}^{2}$ to Armenia and $66,000 \mathrm{~km}^{2}$ to Iran and Turkey). The average height of Kura river watershed upper the Azerbaijan Georgia border is $1,700 \mathrm{~m}$.

Kura river starts from group of streams found in the
Gizil- Gadik mountain at a height of $2,700 \mathrm{~m}$ in Turkey/5/.

The river flows through the territories of Turkey, Georgia and Azerbaijan Republics.

The second large river is Araz. The river flows through Turkey, Armenia and Azerbaijan territories and falls into the Kura near Sabirabad town. The total length of the river is $1,072 \mathrm{~km}$ with a total watershed area of $102,000 \mathrm{~km}^{2}$ (of which $18,740 \mathrm{~km}^{2}$ relates to Azerbaijan , 22,090 $\mathrm{km}^{2}$ to Armenia and $61,000 \mathrm{~km}^{2}$ to Iran and Turkey).

Ganikh (Alazan) is the third large river which flows through the territory of Georgia and Azerbaijan and falls into Mingechaur reservoir (Kura river). The total length of the river is $413 \mathrm{~km}$ with a total watershed area of $12,080 \mathrm{~km}^{2}$ and height of watershed $900 \mathrm{~m}$.

The Samur river's watershed area is $3,620 \mathrm{~km}^{2}$ and Astarachay river's $242 \mathrm{~km}^{2}$.

The watershed areas of rivers which fall directly into the Caspian Sea from North-East slope of Grate Caucasus and Lenkoran-Astara zone are $22,500 \mathrm{~km}^{2}$ and 5,200 $\mathrm{km}^{2}$ consequently. 


\section{Methodology}

In order to assess water resources and climate change impact to them statistical and deterministic methods have been used in this article. In order to assess relationship between the river flow and climatic characteristics of the basins methods of linear regression have been used. Methods of geographical interpretation of flow change by territory have also been used in this work.

\section{Impact of Climate Change on Water Resources}

Our research shows that total water resources of Eastern Caucasus rivers which flow into the Caspian Sea within the Azerbaijan Republic together with the Samur and Astarachay rivers make up $31.5 \mathrm{~km}^{3}$. Total water resources of the Kura river are $26.6 \mathrm{~km}^{3}$ and of the Araz river are approximately $10 \mathrm{~km}^{3}$. Water resources of other rivers directly falling into the Caspian sea (Rivers of the Greater Caucasus North-East slope and Lankaran-Astara zone) make up approximately $4.67 \mathrm{~km}^{3}$, of which $2.17 \mathrm{~km}^{3}$ is related to the Samur river and $0.22 \mathrm{~km}^{3}$ to the Astarachay river. And $25 \%\left(7.5 \mathrm{~km}^{3}\right)$ of total water resources of rivers are formed within the Azerbaijan Republic.

There are more than 10,000 rivers in this territory including small shallow rivers. Drainage density makes up $0.36 \mathrm{~km} / \mathrm{km}^{2}$ across the Azerbaijan Republic that is two times less in comparison with neighboring countries of Caucasus, where upper parts of basins of transboundary rivers are located. The river grid in arid areas of Kura-Araz lowlands is less developed. Many rivers of Shirvan zone are drying up in summer beyond reaching of sea or main river due to the lack of atmospheric precipitation and the high level of evaporation.

As a water poor region, water supply over the Azerbaijan Republic territory makes up about 100,000 $\mathrm{m}^{3} / \mathrm{km}^{2}$. The quotient amounts to an average of about $1,000 \mathrm{~m}^{3}$ of water per person per year, putting the Azerbaijan Republic to one of the low rankings in the world. Water resources of the Republic are distributed very irregularly over administrative districts. Water resources of Sheki-Zakatala zone, Khachmaz and Kelbajar economic districts exceed those in other areas. Absheron and Kura-Araz lowlands are the most water poor regions. During the period of vegetation the river run-off amount is only 10-20\% of the annual amount and in the Lenkaran-Astara zone it does not exceed 5\%.

According to Budiko classification the territory of Eastern Caucasus falls into the insufficient rain fall climate zone, with the lower part of Kura river basin in the arid zone. Therefore, it was necessary to redistribute run-off from one part of the territory to another by means of various kind of water economy facilities.

Presently in the territory of Eastern Caucasus there are many water reservoirs with a purpose to provide the population, industry, irrigation, energy and other sectors with water and to carry out annual and long-term run-off regulation. Further development of the water use facilities will lead to increased use of water resources.

In spite of existence of a huge number of water facilities on the territory, needs in water provision still remain. It is connected to limited water resources and a lack of an economical water use scheme.

At present water resources of Kura and Ganikh in Georgia and water resources of Araz in Turkey, Iran and Armenia are decreased by $20 \%$ as a result of water intake. Also by taking into account of water loss from the channel (river-bed) of Kura river lower course, one may find that available at Azerbaijan Republic water resources of transboundary rivers of Eastern Caucasus at present is less than natural ones by $30 \%$. About $11-12$ cubic $\mathrm{km}$ of water in the Kura river basin is being used for different purposes. Of which $60-70 \%$ goes to agriculture, $20-25 \%$ to economy and the rest for water supply of cities and other residential areas $/ 1$ and $5 /$.

Climate change impact assessment on run-off of 
rivers falling into the Caspian Sea within the Azerbaijan Republic is also undertaken in this work. In this purpose the annual and seasonal values of natural and disposed (available in the rivers of the territory of the country) river run-off are estimated by using a large number of initial material. The spatial-temporal assessment of change of run-off, temperature and precipitation over the river basin has been undertaken. Annual, seasonal and ecological run-off amounts of Kura river in Salyan station and other rivers of the Republic were restored/1 and 3/.

For three upstream basin areas (Upstream of Kura itself, upstream of main tributary Araz and basin of second largest tributary Alazan) following regression equations between annual average water discharges $(\mathrm{Q})$, air temperature $(\mathrm{t})$ and precipitation $(\mathrm{x})$ at the sub basins have been obtained:

(1) For Araz river basin upper Gizilvank hydrological station:

$$
Q=0.243 X-10.2 t+115 \mathrm{~m}^{3} / \mathrm{sec}
$$

(2) For Kura river basin upper Tbilisi hydrological station

$$
Q=0.18 X-11.1 t+92.5 \mathrm{~m}^{3} / \mathrm{sec}
$$

(3) For Ganikh river basin upper Ayrichay hydrological station:

$$
Q=0.20 X-8 t+52 \mathrm{~m}^{3} / \mathrm{sec}
$$

Run-off of Kura river at the Salyan stations (Qsal) near the mouth has been calculated by the following equation of its dependence from the sum of water discharges at three above mentioned stations (Qsum):

$$
Q \text { sal }=1.34 Q \text { sum }+60.1 \mathrm{~m}^{3} / \mathrm{sec} .
$$

Similar models for seasonal run-off amounts have been developed as well.

As Climate Change models the following scenarios had been used: GISS (Increase of annual air temperature by $4.8-5.3{ }^{\circ} \mathrm{C}$ and annual precipitation by 6-12\%), GFDL-3 (Increase of annual air temperature by $4.2-4.4{ }^{\circ} \mathrm{C}$ and annual precipitation by $1-4 \%$ ) climate change models and scenario recommended by specialists of Azerbaijan Academy of Science (about air temperature increase by 2 degrees).
Taking into account changes of air temperature and precipitation in accordance with climate change scenarios based on amounts of the available for today at the territory of Azerbaijan (observed) annual run-off of Kura and potential water resources of the it (Natural run off amounts) the climate change impact to the water resources of Kura has been estimated.

As it is seen from Table 1 by all models from 10 to $20 \%$ decrease of water resources of the river is expected in the future if there are now adequate measures of adaptations.

Results of undertaken work show that annual and seasonal amounts of ecological flow (the minimal monthly run-off necessary for existence of river ecosystem) of Kura river also get reducing by all three of given climate change models with the air temperature increase (Table 2).

It is revealed that atmosphere precipitation increase prevents run-off to reduce except relative amounts of winter run-off.

Identification of adaptation feasibility of water resources to remove negative consequences of climate change is the final stage of quantitative assessment of vulnerability. Basic task of this stage is to identify feasible adaptation measures which should be realized with purpose to prevent climate change consequences and to contribute to stable development of the country.

It is shown that without measures of adaptation occurs hard situation with water provision under all climate change scenarios and more difficult situation are caused by GFDL-T scenario, that is water resources may be reduced about by $40 \%$. In this case the most vulnerable economic branches become energy, agriculture sectors and provision of population with fresh water.

For different branches of economy the climate change impact assessment carried out and ways of its negative consequences mitigation determined. Several adaptation measures are given.

As one of ways to execute necessary adaptation measures to facilitate water resources management in 
Table 1 Change of water discharges of Kura river under climate change models.

\begin{tabular}{|c|c|c|c|c|c|}
\hline \multirow[b]{2}{*}{ Run-off ranges } & \multicolumn{5}{|c|}{ Water discharges, $\mathrm{m}^{3} / \mathrm{sec}$} \\
\hline & Winter & Spring & Summed & Autumn & Annual \\
\hline & XII-II & III-V & VI-VIII & IX-XI & XII-XI \\
\hline \multicolumn{6}{|c|}{ Initial scenario (1961-1990 гг) } \\
\hline Natural & 403 & 1,528 & 897 & 524 & 840 \\
\hline Percent of seasonal values of natural run-off from their annual sum & 12.1 & 45.8 & 26.8 & 15.6 & 100 \\
\hline Observed & 334 & 1,233 & 684 & 400 & 663 \\
\hline Percent of seasonal values of observed run-off from their annual sum & 12.6 & 46.5 & 25.8 & 15.1 & 100 \\
\hline \multicolumn{6}{|c|}{$\Delta \mathrm{t}=2{ }^{\circ} \mathrm{C}, \Delta \mathrm{R}=0 \%$ (scenario supposed by the Azerbaijan Academy of Science) } \\
\hline Natural & 398 & 1,391 & 766 & 460 & 755 \\
\hline Percent of seasonal values of observed run-off from their annual sum & 13.2 & 46.0 & 25.3 & 15.1 & 100 \\
\hline Observed & 306 & 1,075 & 592 & 354 & 583 \\
\hline Percent of seasonal values of observed run-off from their annual sum & 13.1 & 46.1 & 25.3 & 15.1 & 100 \\
\hline \multicolumn{6}{|l|}{ GISS } \\
\hline Natural & 357 & 1,273 & 756 & 412 & 698 \\
\hline Percent of seasonal values of natural run-off from their annual sum & 12.8 & 45.0 & 27.1 & 14.8 & 100 \\
\hline Observed & 255 & 966 & 574 & 312 & 527 \\
\hline Percent of seasonal values of observed run-off from their annual sum & 12.8 & 45.3 & 27 & 14.7 & 100 \\
\hline \multicolumn{6}{|l|}{ GFDL-3 } \\
\hline Natural & 341 & 1,319 & 682 & 390 & 682 \\
\hline Percent of seasonal values of natural run-off from their annual sum & 12.5 & 48.5 & 25.0 & 14.3 & 100 \\
\hline Observed & 272 & 1,081 & 437 & 291 & 520 \\
\hline Percent of seasonal values of observed run-off from their annual sum & 13.1 & 52 & 21 & 14 & 100 \\
\hline
\end{tabular}

Table 2 Ecological run-off (water discharges, cub. $\mathrm{m} / \mathrm{sec}$.) of Kura river near mouth under climate change.

\begin{tabular}{|c|c|c|c|c|c|c|c|c|c|c|c|c|c|}
\hline \multirow{2}{*}{ River-station } & \multicolumn{12}{|c|}{ Monthly ecological run-off, cub. m/sec. } & \multirow[t]{2}{*}{ Annual } \\
\hline & 1 & 2 & 3 & 4 & 5 & 6 & 7 & 8 & 9 & 10 & 11 & 12 & \\
\hline $\begin{array}{l}\text { Kura-Salyan } \\
\text { Actual (observed) }\end{array}$ & 286 & 298 & 366 & 645 & 760 & 547 & 218 & 147 & 197 & 238 & 273 & 280 & 354 \\
\hline Kura-Salyan by GISS & 268 & 275 & 311 & 544 & 660 & 426 & 201 & 120 & 137 & 199 & 248 & 267 & 305 \\
\hline $\begin{array}{l}\text { Kura-Salyan by } \\
\text { GFDL-3 }\end{array}$ & 252 & 263 & 295 & 520 & 624 & 406 & 161 & 91 & 125 & 191 & 228 & 254 & 284 \\
\hline
\end{tabular}

condition of water deficiency it is prepared some project proposals directed to increasing of forest areas in the basins of small and large rivers and creation of water protection zones and water reservoirs (which may also be used for production of hydro energy instead of thermal power plants). The amounts of underground waters have also been indicated for use in different region as sources of safe drinking water. Available for use in this purpose ground water resources volume will be about y $25-30 \%$ from surface waters.

Others relate to decreasing the water losses through improvement of water supply and distribution system and use of modern technology, adoption of measures on use of water recycling and treatment practices, increasing of efficiency of water use, transfer to integrated water resources management on the basis of ecosystem approach.

Implementing of mentioned measures may play positive role in decreasing the negative impact of climate change to water resources of the basin.

For example vulnerability of Energy sector of Azerbaijan to climate change is given in Table 3.

Series of Hydro energy plants has been recommended at different tributaries of Kura with total increase of energy production /4/. 
Table 3 Vulnerability of energy sector of Azerbaijan to climate change.

\begin{tabular}{|c|c|c|c|c|}
\hline \multirow[t]{2}{*}{$\begin{array}{l}\text { Run-off frequency } \\
\mathrm{P} \%\end{array}$} & \multicolumn{2}{|c|}{$\begin{array}{l}\text { Decrease of energy production in comparing with actual situation } \\
(\mathrm{mln} . \mathrm{kWh})\end{array}$} & \multicolumn{2}{|c|}{$\begin{array}{l}\text { Expected damage } \\
\text { (Mln. US\$) }\end{array}$} \\
\hline & GISS & GFDL-3 & GISS & GFDL-3 \\
\hline 50 & 355 & 473 & 14.20 & 18.9 \\
\hline 75 & 280 & 370 & 11.20 & 14.85 \\
\hline 95 & 210 & 290 & 8.40 & 11.6 \\
\hline
\end{tabular}

Table 4 Change of water economy balance of Azerbaijan Republic for different climate change models.

\begin{tabular}{lllll}
\hline \multirow{2}{*}{ Components of the balance } & \multirow{2}{*}{$\begin{array}{l}\text { Existing } \\
\mathrm{mln} . \mathrm{m}^{3}\end{array}$} & $\begin{array}{l}\mathrm{c} \text { Expected quantity of water, mln. } \mathrm{m}^{3} \\
\mathrm{n}=2^{\circ} \mathrm{C},\end{array}$ & GISS & GFDL-3 \\
\hline Water use & 27,887 & 28,976 & 28,976 & 28,976 \\
Water losses & 3,000 & 3,500 & 3,500 & 3,500 \\
Water use and losses together & 30,887 & 32,476 & 32,476 & 32,476 \\
Existing surface waters & 23,400 & 20,995 & 20,200 & 19,000 \\
Use of water from transboundary river Samur & 1,000 & 1,000 & 1,000 & 1,000 \\
Water deficit & 6,487 & 10,481 & 11,276 & 12,476 \\
\hline
\end{tabular}

Table 5 Adaptation measures have been identified to mitigate the expected water deficits in Azerbaijan.

\begin{tabular}{|c|c|c|c|c|}
\hline \multirow[b]{2}{*}{ Planned measure } & \multicolumn{4}{|c|}{ Quantity of water, mln. $\mathrm{m}^{3}$} \\
\hline & $\begin{array}{l}\text { Existing, } \\
\mathrm{mln} . \mathrm{m}^{3}\end{array}$ & $\begin{array}{l}\mathrm{By} \\
\mathrm{dT}=2^{\circ} \mathrm{C}, \\
\mathrm{dR}=0\end{array}$ & GISS & GFDL-3 \\
\hline 1. Water deficit & 6,487 & 10,481 & 11,276 & 12,476 \\
\hline 2. Ground waters available for yearly exploitation & 3,400 & 3,500 & 3,500 & 3,500 \\
\hline 3. Economy of water in result of reconstruction of water supply network & 4,500 & 4,500 & 4,500 & 4,500 \\
\hline 4. Cleaning of about $40 \%$ of polluted waters & 2,000 & 2,500 & 2,500 & 2,500 \\
\hline 5. Decrease of deficit in result of measures & $+3,413$ & 0 & 776 & 1,976 \\
\hline
\end{tabular}

Use of hydro energy potential of rivers leads to decreasing of use of fuel (mazut) for production of energy by thermal power plants, resulting with decrease of emissions of greenhouse gases into atmosphere. Actually thermal plants are located at large cities and there are huge energy losses during its production and dissemination, in a result of use of up-to-date technology. Most of rural areas may more effectively produce hydroenergy resources of nearest rivers rather than use energy of remote thermal power plants.

For the Alazan pilot river basin is calculated the degree of decrease of $\mathrm{CO}^{2}$ emission in the case of use of hydro energy resources of the basin instead of thermal energy (mazut). Results of research show that in this case we will not have such amounts of losses of energy occurred during transportation of thermal energy from power plant located at distance about 300 $\mathrm{km}$ and because of bad condition of disseminating system. Produced hydro energy will be transmitted to nearest residential areas located at the basin of the river. Effective use of hydroenergy potential of region may approximately halve the use of fuel (mazut) and lead to mitigation of amounts of $\mathrm{CO}^{2}$ emission from the energy sector of the region.

\section{Conclusions}

As climate change lead to significant reduction of water resources of Eastern Caucasus rivers therefore there is need to take urgent measures to reduce vulnerability of water resources and water allocation to climate change.

As a summary of all mentioned the main directions of adaptation measures are shown as followings:

(1) Development of IWRM plans;

(2) Decrease of water deficits resulted with low 
efficiency of existing water distribution network by their reconstruction.

(3) Use of underground waters and water recycling. Change of water economy balance of Azerbaijan republic for different climate change models is given in Table 4.

Following adaptation measures have been identified to mitigate the expected water deficits in Azerbaijan (Table 5).

As is shown in Table 5, if undertaking this measures there would not be water deficit today and in the future their amounts expected in accordance with climate change model could be minimized.

\section{References}

[1] Verdiyev, R. H., Mansimov, M. R., and Mamedov, D.
M. 1998. 1998. "Modelling of Hydrological Ranges with Considering Annual River Runoff Distribution." Stochastic Models of Hydrological Processes and Their Applications to Problems of Environmental Preservation: 166-8.

[2] Imanov, F., and Verdiyev, R. 1998. "Estimation of Changes of Natural and Ecological Run-Off of Kur River for Different Climate Change Models." Ecological Problems of Caspian Sea and Ecological Education in Caspian Countries: 62.

[3] Verdiyev, R. 1999. "Water Resources Assessment for the River Kura in Conditions of Climate Change." World Meteorological Organization Bulletin: 327-8.

[4] Verdiyev, R., Mansimov, M., and Imanov, F. 1999. "The Role of Meteorology in Economy of the Azerbaijan Republic." Thesis of presentation. IV European Conference on Application of Meteorology: 13-7, 56-63.

[5] Verdiyev, R. 2002. Water Resources of Eastern Caucasus Rivers under Climate Change. Baku, 214. 